\title{
The Influence of Auditor Opinion, Audit Committee, Discretionary Accrual on Corporate Performance and Cumulative Abnormal Return (Evidence From Indonesia Stock Exchange)
}

\author{
Indrayati ${ }^{1}$, Basuki Rahmat ${ }^{1} \&$ Kuni Utami Handayawati ${ }^{1}$ \\ ${ }^{1}$ Accounting Department, Politeknik Negeri Malang, Indonesia \\ Correspondence: Indrayati, Lecturer, Accounting Department, Politeknik Negeri Malang, Jln. Soekarno-Hatta, No. 9 \\ Malang Jawa Timur, Indonesia.
}

Received: September 25, 2020

Accepted: November 11, 2020

Online Published: January 19, 2021

doi:10.5430/ijfr.v12n2p357

URL: https://doi.org/10.5430/ijfr.v12n2p357

\begin{abstract}
This research aimed to analyze and determine the influence of auditor opinion, audit committee, and discretionary accrual onthe cumulative abnormal return of a company using corporate performance as a moderating variable in the agricultural, basic chemical industry, food and beverage, and finance companies listed on the Indonesia Stock Exchange 2016-2019. The data analysis method used path analysis and multiple linear regressions on a research population of 625 companies listed on the Indonesian Stock Exchange 2016-2019. This research used 226 companies as samples. Research result shows that the auditor opinion and audit committee has no significant influence on corporate performance. Discretionary accrual has a significant influence on corporate performance. Auditor opinion, audit committee, and discretionary accrual have no positive influence on cumulative abnormal return. Corporate performance has a significant influence on cumulative abnormal returns.
\end{abstract}

Keywords: auditor opinion, audit committee, discretionary accrual, corporate performance, cumulative abnormal return

\section{Introduction}

Auditor opinion is a statement of opinion given by the auditor / public accountant in examining the fairness of the client's financial statement in accordance with the applicable financial accounting standards in Indonesia. The most favored auditor opinionis the unqualified opinion (WTP). It means that the client's financial statements adhere to financial accounting standards that are applied consistently with the previous year's financial statements. In addition, there are no errors in the presentation of the numbers in the financial statements. WTP is highly favored by investors as it shows the correct financial statements and the performance of financial statements, and increasesshare prices. The Ministry of Finance imposed sanctions on Public Accountants (AP) Kasner Sirumapea and Public Accountants Firm (KAP) Tanubrata, Sutanto, Fahmi, Bambang and Rekan, as auditors of the financial statements of PT Garuda Indonesia (Persero) Tbk. Sanctions were given after the Ministry of Finance examined the AP / KAP regarding the problems of Garuda Indonesia's financial statements for the 2018 financial year.In the examination, the Ministry of Finance found a violation, especially the recognition of revenue from the cooperation agreement with PT Mahata Aero Teknologi. It was not in accordance with accounting standards. License suspension for 12 months (KMK No. 312 / KM.1 / 2019 dated 27 June 2019) was charged against AP Kasner Sirumapea for committing serious violations that significantly affect the opinion of the independent auditor report (Akhdi Martin Pratama, 2019).Some other research on the effect of auditor opinion on cumulative abnormal return shows significant results (Abbot and Peter; Ferdinand, 2008; Lin and Ziao, 2013; Zakaria and Daud, 2013; Wicaksono and Ari, 2011).

Good corporate governance involves management and institutional ownership structures. The presence of a cooperating board of commissaries and the audit committee will increase stock prices. Increased stock prices would increase the return of share ownership for the investors. Devisia's research (2011) stated that governance, using the audit committee as a proxy, has no significant influence on corporate performance affecting stock prices or cumulative abnormal return. Ningsih dan Suryaatmaja (2017) studied the influence of good corporate governance on cumulative abnormal return. The research result shows that good corporate governance has a positive significant influence on the cumulative abnormal return of company shares in the Indonesian Stock Exchange (Chen and Zhao, 
2010; Daniri 2014; DarmawatiRahayu, 2014; Hardikasari, 2011; Handayani, 2017; Theresia, 2015; Jain, 2013; Fachriyah, 2017; Samani, 2008; Garba, 2015; Suryaatmaja, 2017).

Earning management reflected through discretionary accrual, using income smoothing and retained earning management from the accounting period as a proxy, will increase stock prices. Earning management can be used for distributing bonuses, tax payment, incentives, and capital market consideration for an initial public offering on contractual motivation. Istiqomah dan Adhariani (2017) studied the influence of earning management on cumulative abnormal return (AdharianidanIstiqomah, 2017). The research result showed that earning management has a negative influence on cumulative abnormal return. Other research shows that earning management significantly influenced cumulative abnormal return (Jaing and Yeung, 2006; Healy, 1998). Indrayati (2011) studied the influence of auditor opinion and earning management on cumulative abnormal return. The research result showed that auditor opinion has no significant influence on cumulative abnormal return on Indonesian Stock Exchange shares.

Company performance is the achieved result of company management in operating company funds to obtain maximum profit in accordance with company objectives. The profit is usually measured through the return on equity of a company. Ningsih dan Suryaatmaja (2017) studied the influence of management performance on stock return. Research results showed that management performance has a significant influence on stock return.Based on the aforementioned description, the researchers studied The Influence of Auditor Opinion, Audit Committee, and Discretionary Accrual on Cumulative Abnormal Return, using Corporate Performance as Mediating Factor, in the Indonesian Stock Exchange.

\section{Material Studied}

\subsection{Auditor Opinion}

Sukrisno Agoes (2017) stated in the Public Accountant Professional Standards (PSA 29 SA Section (508) that there are 5 types of auditor opinion: 1) Unqualified opinion, 2) Unqualified opinion with explanatory language, 3) Qualified opinion, 4) Adverse opinion, 5) Disclaimer opinion. Luci Wangiti Munere, Mungai John Njangiru, and Susan Wahito Ngungu research (2016) on auditing and Financial Performance found that auditing has a significant influence on financial performance using strong internal control on water company in Kenya.

\subsection{Good Corporate Governance}

Good corporate governance (GCG), according to the Organization for Economic Cooperation Development/OECD (2004), is how the company management being responsible to shareholders. The principles of good corporate governance developed by OEDC (2004) covers 5 factors: a) protection of rights of the shareholders, b) equal treatment of all shareholders, c) role of stakeholders related to the company, d) openness and transparency, e) accountability and responsibility. The five principles of good corporate governance are crucial for management, principal, and agent in managing a company. KNKG (2006) stated that good corporate governance tool covers: a) shared ownership structure of the majority and minority, as well as managerial and public, b) independent commissary board and c) audit committee. Scott (2015) defined good corporate governance (GCG) as a system used by the board to direct, control, and supervise the management of organization resources effectively, efficiently, economically, and productively using the principles of transparency, accountability, responsibility, independence, and fairness to achieve organizational goals. Rahmawati and Handayani research (2017) on GCG practices on financial performance and stock prices stated that the audit committee has a positive and insignificant influence on financial performance. In addition, financial performance has no significant influence on stock prices.

\subsection{Earning Management}

Earning management, according to Scott (2015) is manager action to report earnings that can maximize personal and company interest (shareholders) utilizing accounting policies or accounting methods and accrual transactions. Earning management is conducted by increasing profit, decreasing profit, income smoothing, and retain earning. Earning has a crucial role in showing performance achieved by the management and encourage investment into the company. The increased investment will improve investor cumulative abnormal return. Earning management aims to reduce excessively extreme earnings by increasing or decreasing earnings using discretionary accrual component. The investors prefer unfluctuating and increasing earnings tendency. Watts dan Zimmerman (1986) stated 3 managerial motivation to conduct earning management, namely: bonus plans, debt contracts, political costs, tax motivation, change of leadership, initial public offering (IPO), and information communication with investors. Jiang dan Yeung (2006) research on discretionary accrual and earning management stated that the practice of discretionary accrual may increase corporate earnings and revenues. 


\subsection{Management Performance}

Management Performance is the result achieved by the company during operations in a certain accounting period, which is measured by return on equity (ROE), namely the rate of return on capital obtained from investment (Scott, 2015). Rani, Yadav, and Jain (2013) state that good corporate governance with short-term performance has a positive and significant effect on Abnormal Return.

\subsection{Cumulative Abnormal Return}

Cumulative abnormal return is the total of abnormal return obtained from the company's stock return minus the market return. Stock return is the present stock price minus the previous period's stock price. The market return is the present combined stock price (IHSG) minus the previous period's combined stock price (Scott, 2015).

\subsection{Research Hypothesis}

Ngungu (2016) stated that auditor opinion has a significant influence on company performance.Good company performance will increase company value or stock price. In turn, the stock price will increase the cumulative abnormal return. The formulated hypothesis is described as follows: H1: Auditor opinion has a significant influence on financial performance.

Good corporate governance, using the audit committee as a proxy, influences company performance if the auditor opinion provides good opinion. (Handayani, 2017). The formulated hypothesis is described as follows: H2: Audit committee has a significant influence on financial performance.

Discretionary accrual, by selecting an appropriate accounting method to increase earnings, may increase company performance (Scott, 2015) (Jiang dan Yeung, 2006). The formulated hypothesis is described as follows:H3: Discretionary accrual has a significant influence on financial performance.

Good and improving company performance may increase cumulative abnormal return. (Scott, 2015) (Handayani, 2017). The formulated hypothesis is described as follows: H4: Financial performance has a significant influence on Cumulative abnormal Return.

A good auditor opinion in the form of an unqualified opinion increases investor reaction and cumulative abnormal return. The research hypothesis is described as follows: H5: Auditor opinion has a significant influence on Cumulative Abnormal Return.

Good governance and audit committee encourages unqualified opinion, increasing the investor's trust in the company and cumulative abnormal return (Handayani, 2017). The research hypothesis is described as follows: H6: Audit committee has a significant influence on Cumulative Abnormal Return.

Discretionary accrual, through selecting appropriate accounting methods capable to increase company earnings, increases company performance. In turn, company performance increases cumulative abnormal returns. (Jiang dan Yeung, 2006). The research hypothesis is described as follows: H7: Discretionary accrual has a significant influence on Cumulative Abnormal Return

\section{Method}

\subsection{Data}

This study used a population of 625 companies listed on the Indonesian Stock Exchange. The samples taken were14 Plantation companies, 1 Animal Husbandry companies, 1 Fishery company, 1 Others, 6 Cement companies, 7 Ceramic Porcelain Glass companies, 14 Metal and Allied Product companies, 13 Chemicals companies, 13 Plastic Packaging companies, 5 Animal feed companies, 4 Wood processing companies, 9 Pulp and Paper companies, 31 Food and beverage companies, 5 Cigarettes companies, 10 Pharmacy companies, 6 Cosmetics companies, 5 household equipment companies, 40 Banks, 17 financing institutions, 9 securities companies, 15 Insurance companies in 2016-2019. The total samples were 226 companies taken by purposive sampling. $i$

This research used secondary data and was collected in the form of documentation from the audited financial statements of companies listed on the Indonesian stock exchange in 2016-2019.Data processing andanalysis methods used in this researchwere path analysis and multiple linear regression with the classical assumption, minimum, maximum, mean, and standard deviation and hypothesis test.

\subsection{Research Variable}

Dependent Variable:

1. Company Performance 
Company performance is the result achieved by company management in operating company funds to obtain optimal returns measured by return on equity (ROE), namely net income divided by the level of equity turnover (Brigham, 1993).

$$
\text { ROE }=\text { Net Income }
$$

\section{Common Equity}

2. Cumulative abnormal return

Cumulative abnormal return (CAR) is the total of abnormal return obtained from the company's stock return minus the market return. Stock return is the present stock price minus the previous period's stock price. The market return is the present combined stock price (IHSG) minus the previous period's combined stock price. Scott, 2015).

$$
\mathrm{CAR}=€ \mathrm{AR} \text { it. }
$$

Description:

$$
\begin{aligned}
& \text { CAR it = cumulative abnormal return of company } i \text { on year } t . \\
& \text { AR it = company abnormal return of company } i \text { on year } t \\
& \text { AR it }=\text { R it }- \text { R mt } \\
& \text { R it }=\text { P it- P it/Pit-1 } \\
& \text { Rmt }=\text { IHSGt }- \text { IHSGt-1/IHSGt-1 }
\end{aligned}
$$

Independent Variable:

1. Auditor Opinion

The auditor opinion is the statement of opinion given by the auditor during the examination of a client's financial statements. The examination determined whether a client has complied and applied SAK consistently with the previous year's financial statement. It is described as $1=$ unqualified opinion and $2=$ other opinions, namely unqualified in explanatory language, qualified opinion, adverse opinion, and disclaimer opinion (Sukrisno Agus, 2017).

\section{Good corporate governance}

Good corporate governance is usually measured by the presence of a board of commissioners, audit committee,shares owned by majority and minority, as well asinstitutional and managerial ownership. The good corporate governance measurement was 1 if the audit committee has 5 people and 0 if there are no people in the audit committee (Handayani, 2017).

\section{Earning Management}

Agents conduct earning managementthrough increasing earning, reducing earning, retaining earning, and smoothing earning to distribute bonuses, tax payment, political costs, settlement of debt contracts, IPO, change of leadership, and information communication with investors (Scott, 2015). Earnings management is measured through discretionaryaccruals obtained by a formula based on Healy's model(1998)

$$
\text { TACС it }=\text { ДСа it }- \text { ДСI it }- \text { ДCash it }- \text { ДSTD it }- \text { Dep it }
$$

A it-1

Description:

TACC it $=$ Total accruals of company $\mathrm{I}$ in year $\mathrm{t}$

ДCa it $=$ Change in current assets of company $\mathrm{I}$ in year $\mathrm{t}$

ДСI it $=$ Change in current debt of company I in year $t$

ДCash it $=$ Change in cash and cash equivalents of company $\mathrm{I}$ in year $\mathrm{t}$

ДSTD it $=$ Changes in long-term debt including current debt

Dep it $=$ Depreciation and amortization expense for company $\mathrm{i}$ in year $\mathrm{t}$

A it $-1=$ Total assets of company $i$ in year $\mathrm{t}-1$

$\mathrm{I}=1$................n company

$\mathrm{T}=1$.............t estimated year 
De Angelo's model predicts non-discretionary accruals using the ratio of total accruals for the period before the observation period (TA t-1) compared to the difference in total assets (A t-2). Therefore, De Angelo's model for non-discretionary accruals is as follows:

$$
\text { NDA } \mathrm{t}=\mathrm{TA} \mathrm{t}-1
$$

A $t-1$

Description:

NDA $t=$ The company normal or fair accrual rate in year $t$

TA $\mathrm{t}-1=$ Total company accruals in year $\mathrm{t}-1$

A $\mathrm{t}-1=$ Total assets of the company in year $\mathrm{t}-2$

The discretionary accruals are shown by the difference between the total accruals in year $\mathrm{t}$ divided by A $\mathrm{t}-1$ by the NDA.

$$
\mathrm{DACC} \text { it }=\mathrm{TA} \text { it }-\mathrm{NDA} \text { it }
$$

\subsection{Empiric Model}

The path model or multiple linear regression with the standardized coefficient explains the functional relationship of the Auditor Opinion (X1), Audit Committee $\left(\mathrm{X}_{2}\right)$, and Discretionary Accrual (X3) to Performance (Y1) and CAR-Cumulative Abnormal Return (Y2) variables. The model is described as follows:

Model 1

$$
\text { Performance }=\beta_{1} \text { Auditor Opinion }+\beta_{2} \text { Audit Committee }+\beta_{3} \text { Discretionary Accrual }+\mathrm{e}
$$

Model 2

$$
\mathrm{CAR}=\beta_{4} \text { Performance }+\beta_{5} \text { Auditor Opinion }+\beta_{6} \text { Audit Committee }+\beta_{7} \text { Discretionary Accrual }+\mathrm{e}
$$

Description:

$\beta_{1}=$ Auditor Opinion to Performance Coefficient

$\beta_{2}=$ Audit Committeeto Performance Coefficient

$\beta_{3}=$ Discretionary Accrual to Performance Coefficient

$\beta_{4}=$ Performance to CAR Coefficient

$\beta_{5}=$ Auditor Opinion to CAR Coefficient

$\beta_{6}=$ Audit Committeeto CAR Coefficient

$\beta_{7}=$ Discretionary Accrual to CAR Coefficient

\section{Finding and Result}

The path model or multiple linear regressions using the Standardized Coefficient above shows that equation (1)

\begin{tabular}{|c|c|c|c|c|c|c|c|c|c|}
\hline Variable & & Coefficient & $\begin{array}{l}\text { Total } \\
\text { Influenc }\end{array}$ & & $\begin{array}{l}\text { Simultaneous } \\
\text { Hypothesis }\end{array}$ & & $\begin{array}{l}\text { Partial } \\
\text { Hypothesis }\end{array}$ & & Description \\
\hline Exogenous & Endogenous & & $\mathrm{R}^{2}$ & $(\%)$ & F hitung & p-value & t-value & p-value & \\
\hline $\begin{array}{l}\text { Auditor } \\
\text { Opinion (X1) }\end{array}$ & & 0,001 & & & & & 0,008 & 0,993 & $\begin{array}{l}\text { Insignificant } \\
\text { Influence }\end{array}$ \\
\hline $\begin{array}{l}\text { Audit } \\
\text { Committee } \\
\text { (X2) }\end{array}$ & $\begin{array}{l}\text { Performance } \\
(Y 1)\end{array}$ & 0,035 & 0,351 & $35,1 \%$ & 9,412 & 0,000 & 0,425 & 0,672 & $\begin{array}{l}\text { Insignificant } \\
\text { Influence }\end{array}$ \\
\hline $\begin{array}{l}\text { Discretionary } \\
\text { Accrual (X3) }\end{array}$ & & 0,327 & & & & & 10,68 & 0,000 & $\begin{array}{l}\text { Significant } \\
\text { Influence }\end{array}$ \\
\hline
\end{tabular}
explains the hypotheses $\mathrm{H}_{1}, \mathrm{H}_{2}$, and $\mathrm{H}_{3}$. Equation (2) explains the hypotheses $\mathrm{H}_{4}, \mathrm{H}_{5}, \mathrm{H}_{6}$, and $\mathrm{H}_{7}$. The results of the hypothesis test are described as follows.

Table 1. Summary of path analysis test 


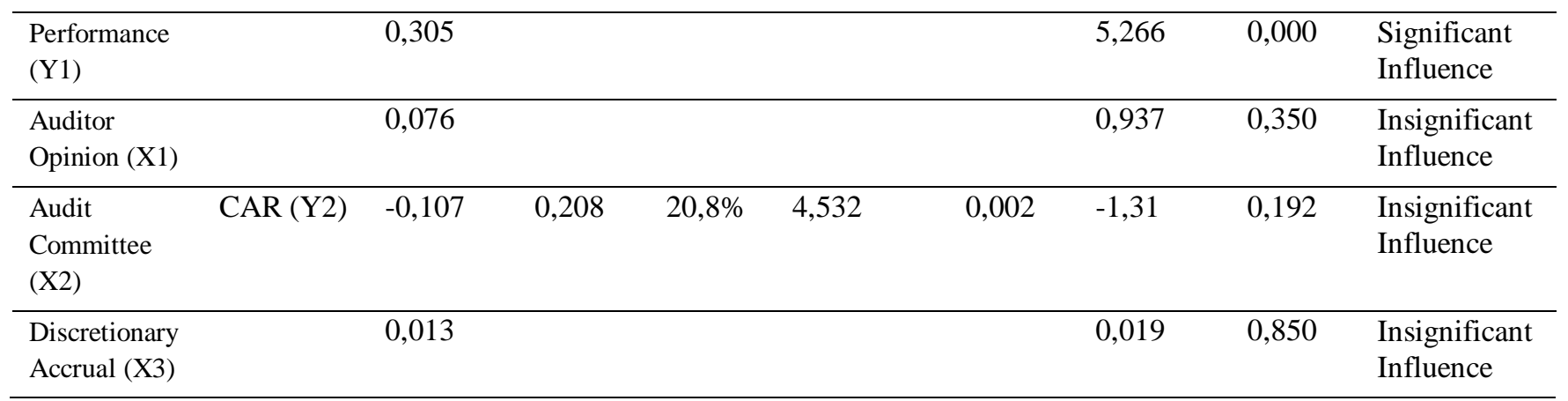

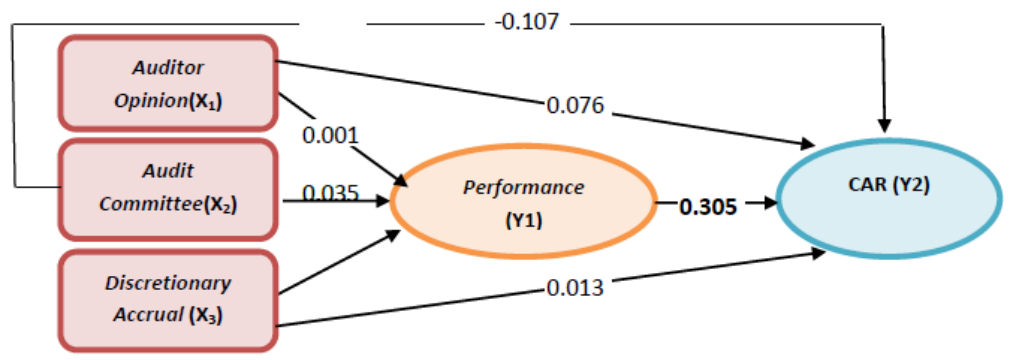

Figure 1. Path analysis diagram

Table 1 shows the estimation and hypothesis test results simultaneously. Model 1 shows F-count value of 9,412 with a p-value of 0.000 . The $\mathrm{p}$-value is smaller than alpha $(0,05)$, therefore the statistical hypothesis states that Ho is rejected. It indicates that the Auditor Opinion $\left(\mathrm{X}_{1}\right)$, Audit Committee $\left(\mathrm{X}_{2}\right)$, and Discretionary Accrual (X3) have a significant influence on Performance ( Y1) simultaneously. Model 2 shows F-count value of 4,532 with a p-value of 0.002. The p-value is smaller than alpha $(0,05)$, therefore the statistical hypothesis states that Ho is rejected. It indicates that the Auditor Opinion (X1), Audit Committee $\left(\mathrm{X}_{2}\right)$, Discretionary Accrual (X3), and Performance (Y1) has a significant influence on CAR (Y2) simultaneously. Furthermore, the hypothesis is partially (individually) described in the following paragraph.

Table 1 shows the Auditor Opinion (X1) influence on Performance (Y1). The coefficient is 0,001 with a p-value of 0,993 . Because the p-value is greater than alpha $(0,05)$, Auditor Opinion (X1) has no significant influence on Performance ( Y1). The Audit Committee (X2) influence on Performance (Y1) shows a coefficient of 0,035 with a $\mathrm{p}$-value of 0,672 . Because the p-value is greater than alpha $(0,05)$, the Audit Committee (X2) has no significant influence on Performance (Y1). Discretionary Accrual (X3) influence on Performance (Y1) shows a coefficient of 0,327 with a p-value of 0,000 . Because the p-value is smaller than alpha $(0,05)$, Discretionary Accrual (X3) has a significant influence on Performance (Y1). Performance (Y1) influence on CAR (Y2) shows a coefficient of 0,005 with a p-value of 0,000. Because the p-value is smaller than alpha $(0,05)$, the Performance (Y1) has a significant influence on CAR (Y2). Auditor Opinion (X1) influence on CAR (Y2) shows a coefficient of 0,076 with a p-value of 0,350 . Because the p-value is greater than alpha $(0,05)$, Auditor Opinion (X1) has no significant influence on CAR (Y2). Audit Committee (X2) influence on CAR (Y2) shows a coefficient of $-0,107$ with a p-value of 0,192. Because the p-value is greater than alpha $(0,05)$, the Audit Committee (X2) has no significant influence on CAR ( Y2). Discretionary Accrual (X3) influence to CAR (Y2) shows a coefficient of 0,013 with a p-value of 0,850 . Because the p-value is greater than alpha (0,05), Discretionary Accrual (X3) has no significant influence on CAR (Y2).). 


\subsection{Descriptive Analysis of Research Data}

Table 2. Frequency Distribution of Research Variables

\begin{tabular}{lllll}
\hline Variable & Minimum & Maximum & Mean & Std. Deviation \\
\hline Auditor Opinion (X1) & 4 & 5 & 4.990 & 0.115 \\
\hline Audit Committee (X2) & 0 & 1 & 0.960 & 0.196 \\
\hline Discretionary Accrual (X3) & -3552 & 1 & -15.704 & 236.277 \\
\hline Performance (Y1) & -558 & 1703 & 23.814 & 135.927 \\
\hline CAR (Y2) & 0 & 80 & 1.318 & 6.339 \\
\hline
\end{tabular}

Table 2 shows the respondent's description based on the size of data concentration (Central Tendency). Auditor Opinion Indicator (X1) shows the Minimum value of 4, Maximum value of 5, Mean value of 4.99, and Standard Deviation value of 0.115. The Audit Committee Indicator (X2) shows the Minimum value of 0, Maximum value of 1, Mean value of 0.96, and Standard Deviation value of 0.196. The Discretionary Accrual Indicator (X3) shows the Minimum value of -3552, Maximum value of 1.02185, Average value (Mean) of -15.704 , and the Standard Deviation value of 236.277. The Performance Indicator (Y1) shows the Minimum value of -558.02 , Maximum value of 1702.97, Mean value of 23.814, and a Standard Deviation value of 135.927. The CAR indicator (Y2) shows the Minimum value of 0, a maximum value of 79.832, Mean value of 1.318, and Standard Deviation value of 6.339.

Model 1 normality test results show normal data with One-Sample Kolmogorof-Smirnov test Asymp. Sig. value of 0.877. Auto-correlation shows the Durbin-Watson score of 2.020 between dU and 4-dU. Multicollinearity shows a tolerance value of less than 1 and a VIF value of less than 10. The heteroscedasticity test using the scatter-plot indicates that the points are spread above and below the number 0 on the $\mathrm{Y}$-axis randomly (Appendix).

Model 2 normality test result shows normal data with One-Sample Kolmogorof-Smirnov test Asymp. Sig. value of 0.971. Auto-correlation shows the Durbin-Watson score of 1.992 between dU and 4-dU. Multicollinearity shows a tolerance value of less than 1 and a VIF value of less than 10. The heteroscedasticity test using the scatter-plot shows that the points are spread above and below the number 0 on the Y-axis randomly (appendix).

\section{Conclusion and Limitation}

This study examined the influence of auditor opinion, audit committee, and discretionary accrual on corporate performance and cumulative abnormal returns on the Indonesian stock exchange. The analysis result shows that discretionary accruals have a significant effect on corporate performance. The auditor opinion and audit committee have no influence on corporate performance. This study supports Devisia's (2011) research which stated that auditor opinion and audit committees have no influence on corporate performance. This research does not support Ningsih and Suryaatmaja's (2017) research which stated that the audit committee has a significant effect on corporate performance.

Corporate performance has a significant effect on cumulative abnormal return. Auditor opinion, audit committee, and discretionary accruals have no influence on cumulative abnormal return. This study supports Dewi Adhariani's (2017) research stating that DiscretionaryAccruals have no influence on cumulative abnormal returns. In addition, this research support Indrayati's research (2011) stating that auditor opinion has no significant effect on cumulative abnormal returns. This study supports Ningsih and Suryaatmaja (2017) stating that performance has a significant effect on cumulative abnormal return.

\subsection{Limitation and Suggestion}

This research implies that a good auditor opinion in the form of an unqualified opinion and the existence of an audit committee will not be able to improve performance. However, it is found that a reduction in earnings management can improve performance. While performance can increase cumulative abnormal returns, unqualified opinion and the presence of an audit committeeare not able to affect cumulative abnormal returns.It can be said that the research aboutthe effect of earnings management and performance on cumulative abnormal returns will be able to help investors invest their funds into the company by selecting companies that have good performance and minimize their earnings management 
This research took 226 companies as research samples. The variables used were auditor opinion, audit committee, discretionary accrual, and corporate performance that influence cumulative abnormal return. Future research may increase the sample size to produce a generalized result onthe companies listed on the Indonesian stock exchange. Based on the research limitations, future research may add variables that affect cumulative abnormal returns such as company growth and profit growth (Indrayati, 2011).

\section{References}

Abbot, L. J., Parker, S., \& Peters, G. (n.d.). Auditor Industrz Specialization and Auditor Reporting. Accounting Research, 17(3), 429-455.

Achmad, D. (2014). Membudayakan good corporate governance. Kompas, Kamis 15 April 2004. https://doi.org/10.9774/GLEAF.4700.2004.au.00012

Adhariani, D., \& Istiqomah, A. (2017). Manajemen laba terhadap cumulative abnormal return.

Agoes, S. (2017). Auditing (Pemeriksaan Akuntan Oleh kantor Akuntan Publik). Jakarta: Lembaga Penerbit Fakultas Ekonomi Universitas Indonesia.

Ahmadu, S., Aminu, S., \& Garba, M. dan T. (2015). Corporate governance mechanism and firm financial performance in Nigeria. African Economic Research Consortium, Nairobi, Maret 2005, Department of Economics, Usmanu Danfodiyo Universitz, Sokota, Nigeria.

Arens, A., Elder, R., \& Beaslez, M. (2015). Auditing and assurance services, an attributes: the perceptions of audit partners, and financial statement audit report on share prices and returns, evidence of Iran.

Benyamin, C., Ayers, J. J., \& Yeung, P. E. (2006). Discretinary accruals and earnings management: an analysis of pseudo earnings targets. The Accounting Review, 81(3), 617-652. https://doi.org/10.2308/accr.2006.81.3.617

Chen, J. P., Charles, S. X., \& Zhao, R. (2010). An emerging markets reaction to Initial Cornett. In M. M. J. Marcuss (Ed.), Earnings management, corporate governance and true financial performance.

Darmawati, D., \& Rahayu, K. dan R. G. (2014). Hubungan corporate dan kinerja perusahaan. Prosiding Simposium Nasoinal Akunatnsi 7, Denpasar.

Devisia, Y. (2011). Pengaruh Independensi Auditor, Komitmen Organisasi, Pemahaman Good Governance, Integritas Auditor dan Budaya Organisasi Terhadap Kinerja. Unpublished Disertation.

Ferdinand, A. G., Kim, J.-B., \& Qiu, A. A. (2008). Qualified audit reports: their impact on investment decisions. Accounting Review, 53(3), 642-649.

Forum for Corporate Governance in Indonesia. (2013). Indonesian Company Law. Retrieved from www.fcgi.org.id

Gompers, P. A., Ishii, J. L., \& Metrick, A. (2013). Corporate governance and equity prices. Quarterlz Journal of Economics, (118), 107-155. https://doi.org/10.1162/00335530360535162

Hardikasari, E. (2011). Pengaruh Penerapan Corporate Governance terhadap Kinerja Keuangan pada Industri Perbankan yang Terdaftar di Bursa Efek Indonesia Tahun 2006-2008. Skripsi. Universitas Diponegoro.

Hastuti, T. D. (2015). Hubungan antara good corporate governance dan Struktur Kepemilikan dengan Kinerja Keuangan. Simposium Nasional Akuntansi, VIII.

Healy, P. M., \& Wahlen, J. M. (1998). A Review of The Earning Management Literature and Its Implications for Standard Setting. Accounting Horizon, 13(4), 365-383. https://doi.org/10.2308/acch.1999.13.4.365

Indrayati. (2011). Pengaruh Kandungan Laba Akuntansi, Aktiva Perusahaan, Opini Auditor Terhadap Cumulative Abnormal Return. Studi Empirik di Bursa Efek Indonesia.

Komite Nasional Kebijakan Governance (KNKG). (2006). Pedoman umum good corporate governance Indonesia. Jakarta.

Lin, Y. J., Tang, Q., \& Xiao, J. (2013). An Experimental Studz of Users Responses to Martinez. M.C.P.

Martinez, A. V., \& Benau, M. A. (2004). Reaction of the spanish modified audit opinion: evidence for the shanghai stock exchange, contemporary moradi, mehdi, mahdi salehi, mehrollah rigi / mohsen moenizade.

Organization for Economic Cooperation Developmet/OECD. (2004). Good Corporate Governance. Paris: OECD

Rahmawati, F. I., \& Handayani, S. R. (2017). The influence of GCG on the stock price. Jurnal Akuntansi dan Bisnis, $50(6)$. 
Rani, N., Surendra, S. Y., \& Jain, P. K. (2013). Impac of corporate governance score on abnormal return of merger and acquisitions. Procedia Economics and Finance, 5(2013), 637-646. https://doi.org/10.1016/S2212-5671(13)00075-0

Saiful Iqbal dan Nurul Fachriyah. (2017). Corporate Governance. Sebagai Alat Pereda.

Samani. (2008). Pengaruh Good Corporate Governance and Leverage Terhadap Kinerja Keuangan Pada Perbankan zang Terdaftar di Bursa Efek Indonesia Tahun 2014-2017. Jurnal Manajemen, 10, $20-27$. https://doi.org/10.24912/ja.v20i3.9

Scott. (2015). Financial accounting theory. Ontario: University of Waterloo.

Surya, A., A., \& Sri, A. N. (2017). Kinerja Manajemen terhadap Return Saham.

Suryaatmaja, A., \& Sri, A. N. F. (2017). Good corporate governance terhadap Cumulative abnormal return.

Watts, R., \& Zimmerman, J. L. (1986). Positive accounting theory. New Yersey: Prentice-Hall, Inc.

Wicaksono, A. (2011). Pengaruh laporan audit wajar dengan bahasa penjelasan terhadap abnormal return study empiris pada bursa. Efek Indonesia,Skripsi.

Zakaria, N., \& Daud, B. (2013). Does big 4 affect the earning response coefficient (ERC), Evidence from Malaysia. Journal of Modern Accounting and Auditing, 9(9), 1204-1215.

\section{Appendix A}

\section{Multiple Linear Regression Model 1}

Table 3. Descriptive

Descriptive Statistics

\begin{tabular}{llllll}
\hline & $\mathrm{N}$ & Minimum & Maximum & Mean & Std. Deviation \\
\hline Auditor_Opinion & 226 & 4 & 5 & 4,99 &, 115 \\
\hline Audit_Committe & 226 & 0 & 1 &, 96 &, 196 \\
\hline Discretional_Accrual & 226 & $-3552,00000$ & 1,02185 & $-15,7035173$ & 236,27654658 \\
\hline Performance & 226 & $-558,02$ & 1702,97 & 23,8143 & 135,92717 \\
\hline CAR & 226 &, 0000 & 79,8320 & 1,317714 & 6,3388431 \\
\hline Valid N (listwise) & 226 & & & & \\
\hline
\end{tabular}

Table 4. Correlations

\begin{tabular}{|c|c|c|c|c|c|}
\hline & & Performance & AuditorOpinion & AuditCommittee & DiscretionaryAccrual \\
\hline \multirow[t]{4}{*}{ Pearson Correlation } & Performance & 1,000 &, 020 &, 035 & ,007 \\
\hline & Auditor_Opinion &, 020 & 1,000 &, 570 &,- 008 \\
\hline & Audit_Committee &, 035 &, 570 & 1,000 &,- 014 \\
\hline & Discretionary_Accrual & ,007 &,- 008 &,- 014 & 1,000 \\
\hline \multirow[t]{4}{*}{ Sig. (1-tailed) } & Performance & . & ,380 & ,301 & ,461 \\
\hline & Auditor_Opinion & ,380 & . &, 000 &, 454 \\
\hline & Audit_Committee & ,301 &, 000 & . & ,419 \\
\hline & Discretionary_Accrual & ,461 & ,454 & ,419 & . \\
\hline \multirow[t]{4}{*}{$\mathrm{N}$} & Performance & 226 & 226 & 226 & 226 \\
\hline & Auditor_Opinion & 226 & 226 & 226 & 226 \\
\hline & Audit_Committee & 226 & 226 & 226 & 226 \\
\hline & Discretionary_Accrual & 226 & 226 & 226 & 226 \\
\hline
\end{tabular}


Table 5. Model Summary ${ }^{\mathrm{b}}$

\begin{tabular}{llllll}
\hline Model & $\mathrm{R}$ & $\mathrm{R}$ Square & Adjusted R Square & Std. Error of the Estimate & Durbin-Watson \\
\hline 1 &, $036^{\mathrm{a}}$ & $, 0,151$ &,- 012 & 136,75557 & 2,020 \\
\hline
\end{tabular}

a. Predictors: (Constant), Discretionary_Accrual, Auditor_Opinion, Audit_Committee

b. Dependent Variable: Performance

Table 6. ANOVA ${ }^{\mathrm{a}}$

\begin{tabular}{llllll}
\hline Model & Sum of Squares & df & Mean Square & F & Sig. \\
\hline Regression & 5280,747 & 3 & 1760,249 &, 094 &, $013^{\mathrm{b}}$ \\
\hline Residual & 4151863,026 & 223 & 18702,086 & & \\
\hline Total & 4157143,774 & 223 & & & \\
\hline
\end{tabular}

a. Dependent Variable: Performance

b. Predictors: (Constant), Discretionary_Accrual, Auditor_Opinion, Audit_Committee

Tabel 7. Coefficients ${ }^{\mathrm{a}}$

\begin{tabular}{|c|c|c|c|c|c|c|c|c|}
\hline \multirow{2}{*}{\multicolumn{2}{|c|}{ Model }} & \multicolumn{2}{|c|}{$\begin{array}{l}\text { Unstandardized } \\
\text { Coefficients }\end{array}$} & \multirow{2}{*}{$\begin{array}{l}\text { Standardized } \\
\text { Coefficients }\end{array}$} & \multirow[b]{2}{*}{$\mathrm{t}$} & \multirow[b]{2}{*}{ Sig. } & \multicolumn{2}{|c|}{ Collinearity Statistics } \\
\hline & & B & Std. Error & & & & Tolerance & VIF \\
\hline \multirow[t]{4}{*}{1} & (Constant) & $-3,266$ & 453,567 & &,- 007 & ,004 & & \\
\hline & Auditor_Opinion & ,816 & 96,701 & ,001 & ,008 & ,993 & ,676 & 1,480 \\
\hline & Audit_Committee & 24,029 & 56,600 & ,035 & ,425 & 672 & ,676 & 1,480 \\
\hline & Discretionary_Accrual & ,004 & ,039 & ,007 & , 104 & 017 & 1,000 & 1,000 \\
\hline
\end{tabular}

Table 8. One-Sample Kolmogorov-Smirnov Test

\begin{tabular}{lll}
\hline $\mathrm{N}$ & & Unstandardized Residual \\
\hline Normal Parameters & & 226 \\
\hline Most Extreme Differences & Mean &, 0000000 \\
\cline { 2 - 3 } & Std. Deviation & 135,84080595 \\
\cline { 2 - 3 } & Absolute &, 348 \\
\cline { 2 - 3 } & Positive &, 348 \\
\cline { 2 - 3 } & Negative &,- 344 \\
\hline Test Statistic & &, 348 \\
\hline Asymp. Sig. (2-tailed) & &, $877^{\mathrm{c}}$ \\
\hline
\end{tabular}

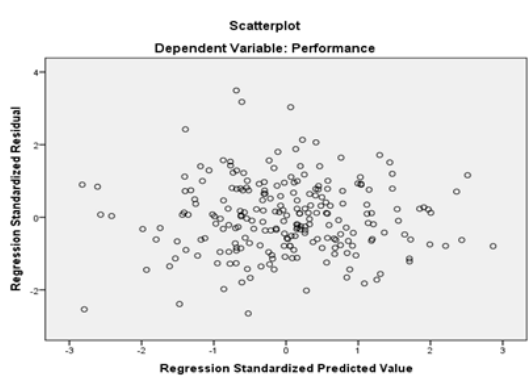

Figure 2. Scaterplot 


\section{Appendix B}

\section{Multiple Linear Regression Model 2}

Table 9. Descriptive Statistics

\begin{tabular}{llll}
\hline & Mean & Std. Deviation & $\mathrm{N}$ \\
\hline CAR & 1,317714 & 6,3388431 & 226 \\
\hline Performance & 23,8143 & 135,92717 & 226 \\
\hline Auditor_Opinion & 4,99 &, 115 & 226 \\
\hline Audit_Committee &, 96 &, 196 & 226 \\
\hline Discretionary_Accrual & $-15,7035173$ & 236,27654658 & 226 \\
\hline
\end{tabular}

Table 10. Correlations

\begin{tabular}{|c|c|c|c|c|c|}
\hline \multirow{3}{*}{$\begin{array}{l} \\
\text { Pearson } \\
\text { Correlation }\end{array}$} & \multirow[b]{2}{*}{ CAR } & \multicolumn{4}{|c|}{ CAR Performance Auditor_Opinion Audit_Committee Discretionary_Accrual } \\
\hline & & $1,000,003$ &, 015 &,- 063 & 014 \\
\hline & Performance & $, 003 \quad 1,000$ &, 020 &, 035 & ,007 \\
\hline & Auditor_Opinion & ,015,020 & 1,000 &, 570 &,- 008 \\
\hline & Audit_Committee & $-, 063,035$ &, 570 & 1,000 &,- 014 \\
\hline & Discretionary_Accrual & ,014,007 &,- 008 &,- 014 & 1,000 \\
\hline \multirow{5}{*}{$\begin{array}{l}\text { Sig. } \\
\text { (1-tailed) }\end{array}$} & CAR &, 484 & ,408 &, 172 & ,419 \\
\hline & Performance &, 484 &, 380 & ,301 & ,461 \\
\hline & Auditor_Opinion & ,408,380 & . & ,000 & ,454 \\
\hline & Audit_Committee & , 172,301 &, 000 & . & ,419 \\
\hline & Discretionary_Accrual & ,419, 461 &, 454 & ,419 & . \\
\hline \multirow[t]{5}{*}{$\mathrm{N}$} & CAR & $226 \quad 226$ & 226 & 226 & 226 \\
\hline & Performance & $226 \quad 226$ & 226 & 226 & 226 \\
\hline & Auditor_Opinion & $226 \quad 226$ & 226 & 226 & 226 \\
\hline & Audit_Committee & $226 \quad 226$ & 226 & 226 & 226 \\
\hline & Discretionary_Accrual & $226 \quad 226$ & 226 & 226 & 226 \\
\hline
\end{tabular}

Table 11. Model Summary ${ }^{\mathrm{b}}$

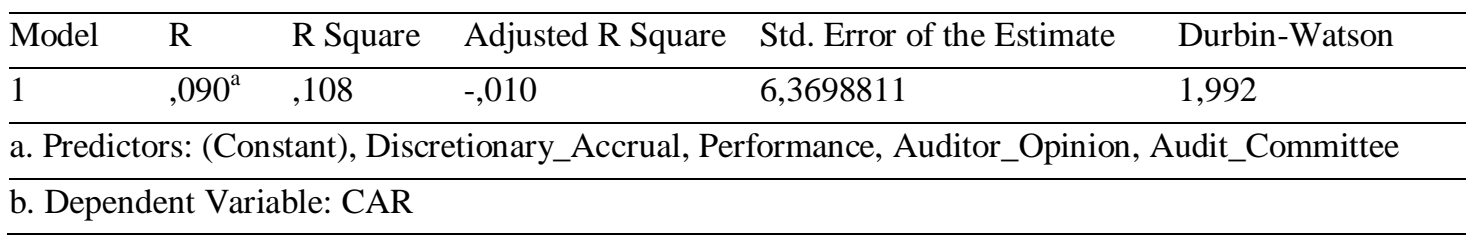

Table 12. ANOVA

\begin{tabular}{lllllll}
\hline Model & & Sum of Squares & df & Mean Square & F & Sig. \\
\hline 1 & Regression & 73,550 & 4 & 18,387 &, 453 &, $027^{b}$ \\
\cline { 2 - 7 } & Residual & 8967,160 & 222 & 40,575 & & \\
\cline { 2 - 7 } & Total & 9040,710 & 222 & &
\end{tabular}

b. Predictors: (Constant), Discretionary_Accrual, Performance, Auditor_Opinion, Audit_Committee 
Table 13. Coefficients ${ }^{\mathrm{a}}$

\begin{tabular}{|c|c|c|c|c|c|c|c|c|}
\hline \multirow{2}{*}{\multicolumn{2}{|c|}{ Model }} & \multicolumn{2}{|c|}{$\begin{array}{l}\text { Unstandardized } \\
\text { Coefficients }\end{array}$} & \multirow{2}{*}{$\begin{array}{l}\text { Standardized } \\
\text { Coefficients } \\
\text { Beta }\end{array}$} & \multirow[t]{2}{*}{$\mathrm{t}$} & \multirow[t]{2}{*}{ Sig. } & \multicolumn{2}{|c|}{$\begin{array}{l}\text { Collinearity } \\
\text { Statistics }\end{array}$} \\
\hline & & B & Std. Error & & & & Tolerance & VIF \\
\hline \multirow[t]{5}{*}{1} & (Constant) & $-16,402$ & 21,127 & &,- 776 & ,438 & & \\
\hline & Performance & ,000 & ,003 & ,005 & ,071 & ,044 & ,999 & 1,001 \\
\hline & Auditor_Opinion & 4,219 & 4,504 & ,076 & ,937 & ,350 & ,676 & 1,480 \\
\hline & Audit_Committe & $-3,455$ & 2,637 &,- 107 & $-1,310$ & , 192 & ,675 & 1,481 \\
\hline & Discretional_Accrual & ,000 & ,002 & ,013 & 190 & 850 & 1,000 & 1,000 \\
\hline
\end{tabular}

Table 14. One-sample kolmogorov-smirnov test

\begin{tabular}{lll}
\hline $\mathrm{N}$ & & Unstandardized Residual \\
\hline Normal Parameters & & 226 \\
\hline Most Extreme Differences & Mean &, 0000000 \\
\cline { 2 - 3 } & Std. Deviation & 6,31300599 \\
\cline { 2 - 3 } & Absolute &, 438 \\
\cline { 2 - 3 } & Positive &, 438 \\
\cline { 2 - 3 } Test Statistic & &,- 392 \\
\hline Asymp. Sig. (2-tailed) & &, 438 \\
\hline
\end{tabular}

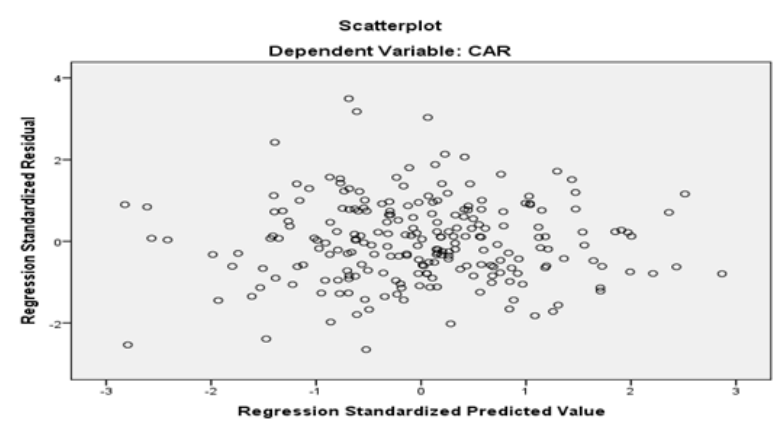

Figure 3. Scarterplot

\section{Copyrights}

Copyright for this article is retained by the author(s), with first publication rights granted to the journal.

This is an open-access article distributed under the terms and conditions of the Creative Commons Attribution license (http://creativecommons.org/licenses/by/4.0/). 